\title{
Editorial
}

\section{Polymers Best Paper Award 2014}

\section{Alexander Böker}

DWI - Leibniz-Institut für Interaktive Materialien, Lehrstuhl für Makromolekulare Materialien und Oberflächen, RWTH Aachen University, Forckenbeckstrasse 50, D-52056 Aachen, Germany; E-Mail: boker@mdpi.com

Received: 14 January 2014 / Accepted: 16 January 2014 / Published: 21 January 2014

Polymers is instituting an annual award to recognize outstanding papers in the area of polymer science published in Polymers.

We are pleased to announce the first "Polymers Best Paper Award" for 2014. Nominations were selected by the Editor-in-Chief and Editorial Board members of Polymers from all papers published in 2010. The awards are issued to reviews and articles respectively. We are pleased to announce that the following three papers were chosen:

\section{Article Award:}

$1^{\text {st }}$ Prize

\section{Yuk-Hong Ting, Chi-Chun Liu, Sang-Min Park, Hongquan Jiang, Paul F. Nealey and}

\section{Amy E. Wendt}

Surface Roughening of Polystyrene and Poly(methyl methacrylate) in $\mathrm{Ar} / \mathrm{O}_{2}$ Plasma Etching Polymers 2010, 2(4), 649-663; doi:10.3390/polym2040649

Available online: http://www.mdpi.com/2073-4360/2/4/649

$2^{\text {nd }}$ Prize

\section{Mariano Pracella, Md. Minhaz-UI Haque and Vera Alvarez}

Functionalization, Compatibilization and Properties of Polyolefin Composites with Natural Fibers Polymers 2010, 2(4), 554-574; doi:10.3390/polym2040554

Available online: http://www.mdpi.com/2073-4360/2/4/554 


\section{Review Award:}

\section{Gilberto Siqueira, Julien Bras and Alain Dufresne}

Cellulosic Bionanocomposites: A Review of Preparation, Properties and Applications Polymers 2010, 2(4), 728-765; doi:10.3390/polym2040728

Available online: http://www.mdpi.com/2073-4360/2/4/728

Fortunately, the Prize Awarding Committee could choose from a large number of high quality publications, so that the selection was a difficult task. Finally, we have identified contributions which represent basic as well as application-oriented research. Moreover, the review which was awarded has already made significant impact in the respective field and is a nice example of the international recognition of open access publishing.

On behalf of the Prize Awarding Committee and the Editorial Board of Polymers, I would like to congratulate these three teams on their excellent work. In recognition of their accomplishment, for the awarded articles, Dr. Amy Wendt and Dr. Mariano Pracella will receive prizes of $600 \mathrm{CHF}$ and $400 \mathrm{CHF}$, respectively, and the opportunity to publish an additional paper free of charge in open access format in Polymers, after the usual peer-review procedure. For his review, Dr. Alain Dufresne will be given the opportunity to publish a research article free of charge in Polymers after the usual peer-review process.

Prize Awarding Committee

Editor-in-Chief

Prof. Dr. Alexander Böker

DWI - Leibniz-Institut für Interaktive Materialien, Lehrstuhl für Makromolekulare Materialien und Oberflächen, RWTH Aachen University, Forckenbeckstrasse 50, D-52056 Aachen, Germany E-Mail: boker@mdpi.com

\section{Editorial Board Members}

\section{Prof. Dr. Martin Kröger}

Polymer Physics, Department of Materials, Swiss Federal Institute of Technology, ETH Zurich, Wolfgang-Pauli-Str. 10, CH-8093 Zurich, Switzerland

E-Mail:mk@mat.ethz.ch

\section{Prof. Dr. Katja Loos}

Department of Polymer Chemistry, Zernike Institute for Advanced Materials, University of Groningen, Nijenborgh 4, 9747 AG Groningen, The Netherlands

E-Mail: k.u.loos@rug.nl 


\section{Prof. Dr. George R. Newkome}

Departments of Polymer Science \& Chemistry, The University of Akron, Akron, OH 44325-4717, USA E-Mail: newkome@uakron.edu

\section{Prof. Dr. Ben Zhong Tang}

Department of Chemsitry, The Hong Kong University of Science \& Technology, Clear Water Bay, Kowloon, Hong Kong, China

E-Mail: tangbenz@ust.hk

\section{Prof. Dr. Philipp Vana}

Makromolekulare Chemie, Institut für Physikalische Chemie, Georg-August-Universität Göttingen, Tammannstraße 6, D-37077 Göttingen, Germany

E-Mail: pvana@uni-goettingen.de

\section{Dr. Wei Min Huang}

School of Mechanical and Aerospace Engineering, Nanyang Technological University, 50 Nanyang Avenue, 639798, Singapore

E-Mail: mwmhuang@ntu.edu.sg

(C) 2014 by the authors; licensee MDPI, Basel, Switzerland. This article is an open access article distributed under the terms and conditions of the Creative Commons Attribution license (http://creativecommons.org/licenses/by/3.0/). 